DOI: 10.1515/arls-2017-0001

Research Article

\title{
Investigation of Foliar Fertilization in Maize Production
}

\author{
Péter Jakab*, Gábor Zoltán, Dávid Festő, Levente Komarek
}

University of Szeged, Faculty of Agriculture Andrássy str. 15. Hódmezővásárhely, Hungary

\begin{abstract}
The experiment was designed to study the effect of foliar fertilisation on the yield and some generative factors of maize in 2016. It was set on the territory of SZTE Tangazdaság Ltd in Hódmezővásárhely meadow chernozem soil. Three different foliar fertilizer products were applied in three replication randomised small plot experiment. The products were sprayed out individually and combined with each other as well, so there were six treatments and the control. In 2016 the amount of precipitation in the vegetation period of maize was higher than the average by 23.7 $\mathrm{mm}$. Therefore this year was favourable for maize production. The data obtained during the experiment were processed by single factor variant analysis. Owing to the favourable dispersion of rainfall in the vegetative period of maize, the yields were relatively high. The average yield harvested from the control plots was $11.37 \mathrm{t} / \mathrm{ha}$, and that of the treated parcels ranged from 11.61 and $12.86 \mathrm{t} / \mathrm{ha}$. The foliar fertilizer products and their combinations increased the yield of maize, but this growing was not significant. By the using of foliar fertilization the generative factors of maize did not change significantly.
\end{abstract}

Keywords: maize, foliar fertilization, grain yield, thousand seed weight, grain moisture content

\section{Introduction}

Maize is one of the plants grown on the largest areas in the world and in Hungary as well. Its production is vital since it is a kind of grain that can be used in many ways. The genetic productivity of the newest maize hybrids is continuously growing. In order that the potential of hybrids productive capacity can be utilized as much as possible, the harmony of the agrotechnical factors is necessary [1].

The low average yield in maize production can be due to the fall-back of chemical fertilization; this is why the use of fertilizers must be increased in order to reach higher and more consistent amounts of crop [2, 3, 4, 5, 6].

Most arable crops obtain the necessary macro and micro elements from the soil. Foliar fertilization is getting more and more widespread,

\section{* Corresponding author: Péter Jakab, jakabpeter@mgk.u-szeged.hu}

(cc) BY-NC-ND $\odot 2017$ Péter Jakab-Gábor et al., published by De Gruyter Open. This work was licensed under the Creative Commons Attribution-NonCommercialNoDerivs 3.0 License however it still requires comprehensive experimental research. Precise, repeated small plot trials must be carried out to clarify the factors influencing the effectiveness of foliar fertilizers and recommendations must be developed for producers [7].

The recent results of the soil tests show that due to the intensive maize production in Hungary the zinc content of soils fell back sharply. The soil might have a relative zinc deficiency even if there is a good supply of zinc. It is caused by the antagonism of phosphorus and zinc uptake in those areas where the phosphorus content of the soil is very high $[8,9,10,11]$.

The foliar fertilization improved the amount of the yield, but the growth was not significant. The yield components of maize did not change statistically justified due to the application of foliar fertilization $[12,13]$.

Foliar fertilizers are unanimously considered stimulating and corrective products for mineral nutrition. They exhibit a secondary fertilizing role, that determines a significant increase of the productive consumption for soil elements and soilapplied elements without substituting root 
fertilization methods (through the soil), where foliar fertilizers are supplementary in balancing and optimizing the fertilization system applied to agricultural and horticultural plants $[14,15,16$, 17].

Nowadays besides the fertilizers even more farmers use different bacterium preparations in nutrient supply of arable crops. This product contains different bacteriums which can improve the nutrient supply of plant. With the application of these products we can reduce the amount of fertilizers, which enables the environmentally friendly and economical production. They improve the physical properties and chemical properties of the soil, and maintain the soil fertility $[18,19,20$, $21,22]$.

\section{Material and Methods}

The experiment was carried out on the territory of Tangazdaság Ltd. in Hódmezővásárhely on nearly neutral meadow chernozem soil ( $\mathrm{pH}_{\mathrm{KCL}}$ 7.17). Before setting the experiment soil analysis was done, and the obtained data showed that the soil had good nitrogen, and very good phosphorus and potassium contents (Table 1).

The main properties of the experimental field area

Table 1

\begin{tabular}{c|c|c|c|c}
\hline pH (KCL) & $\begin{array}{c}\mathbf{P}_{\mathbf{2}} \mathbf{O}_{\mathbf{5}} \\
(\mathbf{m g} / \mathbf{k g})\end{array}$ & $\begin{array}{c}\mathbf{K}_{\mathbf{2}} \mathbf{O} \\
(\mathbf{m g} / \mathbf{k g})\end{array}$ & Humus (\%) & $\begin{array}{c}\text { Soil plasticity value } \\
\left(\mathrm{K}_{\mathbf{A}}\right)\end{array}$ \\
\hline 7.17 & 336 & 620 & 3.39 & 48 \\
\hline
\end{tabular}

The year 2016 was favourable for maize production. In 2016 precipitation in the vegetative period of maize was higher by $23.7 \mathrm{~mm}$ than the 50 year average. In June and July fell more precipitation $(+60 \mathrm{~mm})$ compared the 50 years average. This amount of precipitation affected the generative development phases, the flowering and fertilization, just as the grain filling of maize populations favourable. In September there was an average amount of precipitation, which promoted the drying processes of maize crops and also the harvest works (Table 2).

The applied agro-technology

The small-scale experiment was carried out in three replications, in random blocks. The size of parcels was $7.6 \mathrm{~m}^{2}$. The previous crop was winter wheat. Tillage (deep ploughing at $30 \mathrm{~cm}$ depth) was done in autumn. The sowing date was on 14 th. of April. The examined hybrid was Limanova (FAO 370). The plant density was 70.000 plant/hectare. Foliar fertilization treatments were applied at 6-7 leaves stage. The foliar fertilizer products were applied with a dose suggested by manufacturers. The applied products were the following: 1) Algafix (microbiological biostimulator, that contains live algae which produce cytokinin, a plant hormone to help the shootgrowth of the plant), 2) Amalgerol (a product containing plant oils, herb extracts, trace elements and essence) and 3) Fitohorm Turbo Zn solution (containing $\mathrm{Zn}$, the most important microelement for maize).The products were sprayed out individually and combined with each other as well, so in total there were six treatments and the control. Apart from foliar fertilization the parcels received the same agrotechnology.

The amount of precipitation in the vegetative period of maize in 2016

Table 2

\begin{tabular}{c|c|c|c}
\hline Month & Rainfall $\mathbf{( m m )}$ & $\begin{array}{c}\text { Average rainfall } \\
(\mathbf{m m})\end{array}$ & $\begin{array}{c}\text { Difference } \\
(\mathbf{m m})\end{array}$ \\
\hline April & 19.4 & 39.9 & -20.5 \\
May & 38.8 & 58 & -19.2 \\
June & 86.0 & 75.3 & 10.7 \\
July & 106 & 58.7 & 47.3 \\
August & 47.6 & 48.7 & -1.1 \\
September & 47.2 & 40.7 & 6.5 \\
\hline Total amount of rainfall $(\mathbf{m m})$ & $\mathbf{3 4 5 . 0}$ & $\mathbf{3 2 1 . 3}$ & $\mathbf{2 3 . 7}$ \\
\hline
\end{tabular}


The plots were harvested by hand, then the yield of the parcels, grain humidity, cob: grain yield rates and thousand-grain weight were measured, out of which the shelled grain yield in May was calculated.

In order to perform the analysis, one-way analysis of variance (ANOVA) and Tukey test were applied. ANOVA was used to clarify whether the means of the different treatments (groups) differ significantly. If ANOVA, based on the F-test, detects significant difference among these means, another test is then applied to determine exactly which means differ significantly from the others. Significant differences between the means of different treatments may highlight the impact of the individual treatments on the analyzed parameter.

There are several versions available for comparing means calculated from subsamples of a sample. A relatively simple but effective way is to use the Tukey test [23, 24, 25].

\section{Results and Discussions}

Without foliar fertilization the yield of the hybrid in our experiment was relatively high, $11.37 \mathrm{t} / \mathrm{ha}$. It shows, that this hybrid has good nutrient exploration and utilization capacity. The newer maize hybrids are improved both in the natural nutrient exploration and utilisation capacity and in their reaction of fertilizers.

With the foliar fertilization products the yield ranged between 11.61-12.86 t/ha. The treatments results $0.24-1.49 \mathrm{t} / \mathrm{ha}$ yield increasing compered the control plots. When foliar fertilization was applied, the yield was higher, but this growth was not significant on $\mathrm{P} 5 \%$ level compared to control. We obtained the highest yield in Amalgerol (12.86 $\mathrm{t} / \mathrm{ha})$ and Algafix+Amalgerol (12.34 t/ha) treatments (Figure 1).

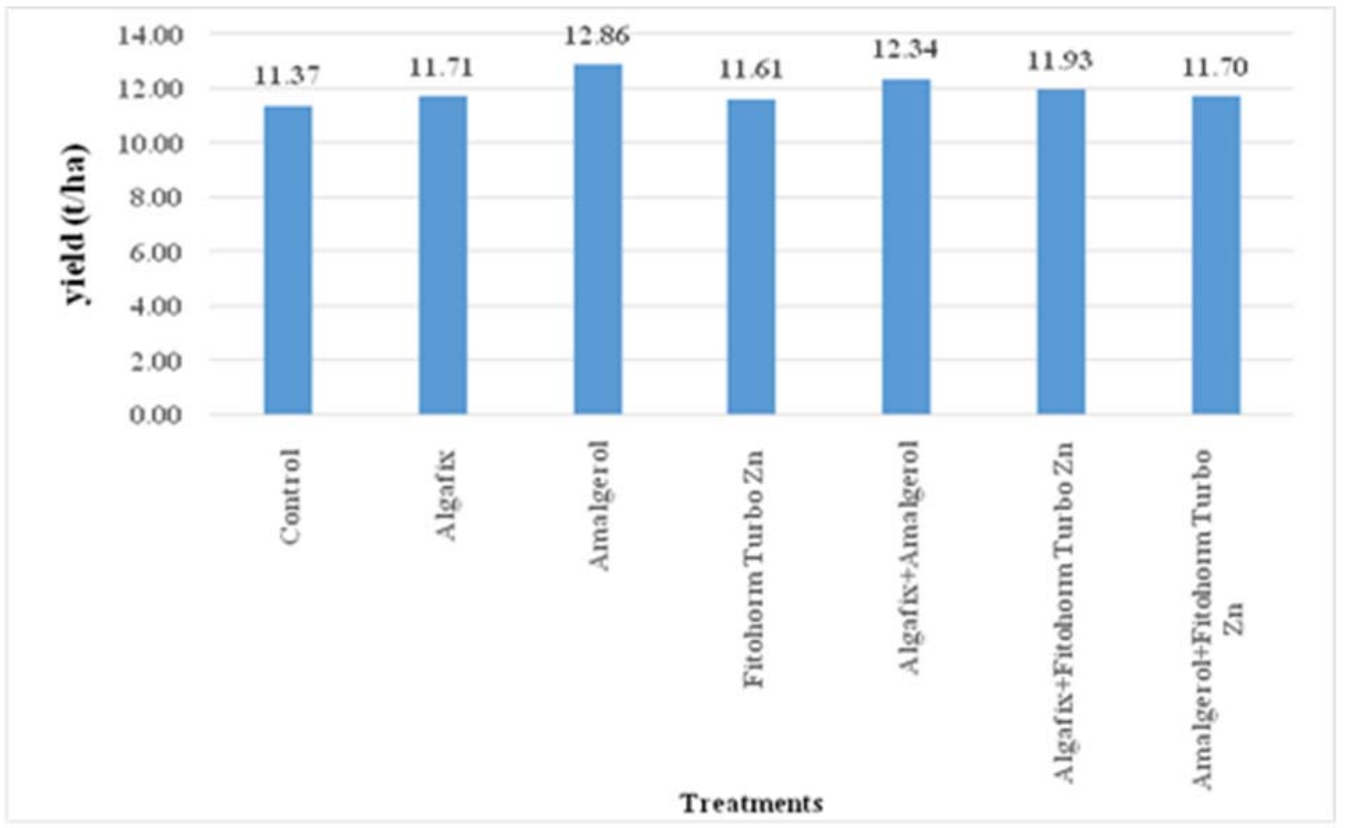

Fig. 1. The maize hybrid yields in control and foliar fertilization treatments

The effect of foliar fertilization was studied on the yield components of maize (thousand grain weight, cob:grain yield rates, grain moisture content at harvest). The yield components are highly dependent on the genetically background of maize hybrid. However, the environmental and cultivation practices are able to influence these values. Among the cultivation practices, the nutrient supply had the highest effect on these properties. The thousand grain weight was 423.33 $\mathrm{g}$ in control treatment. Under the influence of foliar fertilizers, the thousand grain weight ranged between 403.33 and $430.00 \mathrm{~g}$. The highest values of thousand grain weight $(430.00 \mathrm{~g})$ we measured in Fitohorm Turbo $\mathrm{Zn}$ and Algafix+Fitohorm Turbo $\mathrm{Zn}$ treatments (Figure 2.) The change of thousand grain value compared the control was not significant on $\mathrm{P}=5 \%$ level. 


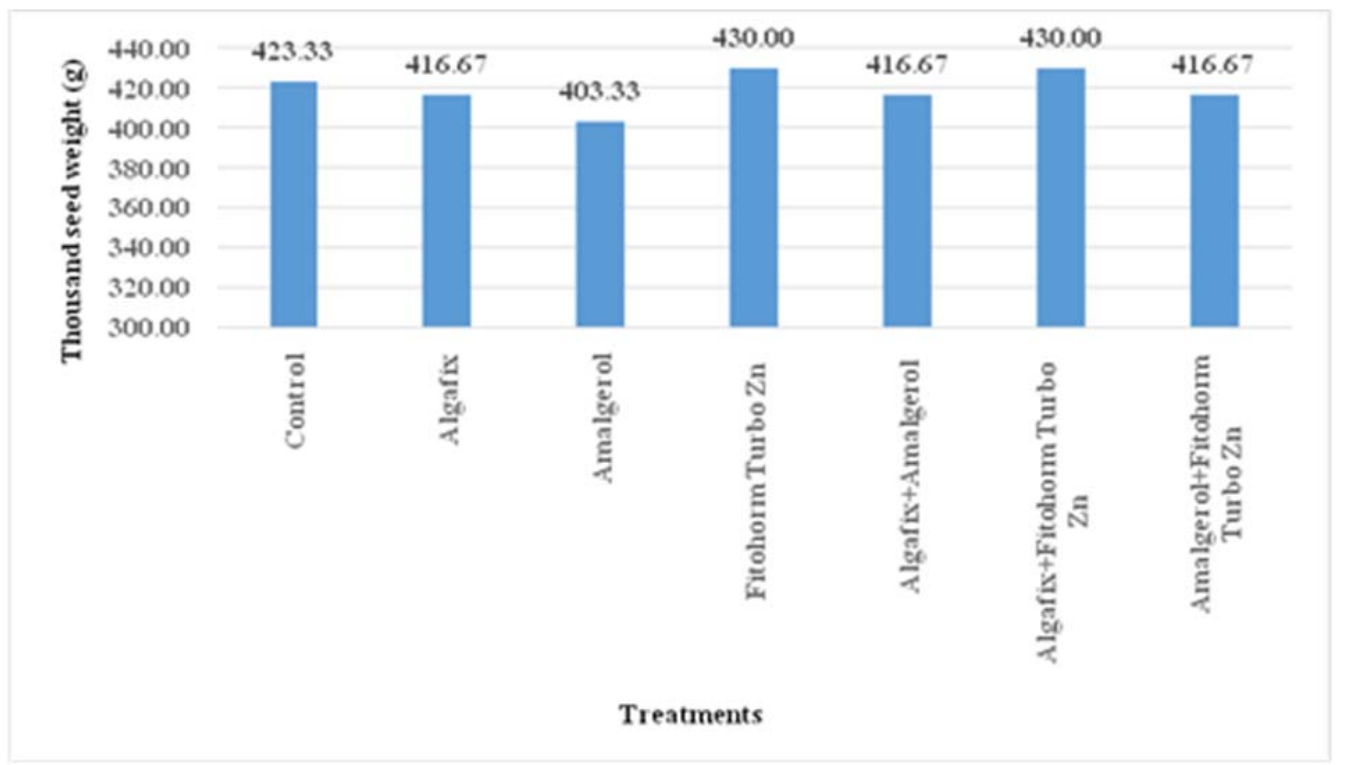

Fig. 2. The effect of foliar fertilization on the thousand seed weight of maize

The average yield of maize is influenced by the cob:grain yield ratio. The larger the weight of grain, compared to the weight of the cob, the higher the yield is. One important objective for breeding is to increase the proportion of the grain. The cob: grain yield rates of the new hybrids are more than $80 \%$, sometimes approach $90 \%$. The cob: grain yield rates of hybrids are greatly influenced by the genetic traits of the hybrids, which can be altered only to a slight extent by different agrotechnical elements. It is also proved by our experiment results, as the value of the control treatment did not change significantly the different treatments. The cob: grain yield rates of the maize hybrid increased most by Algafix (89.99\%) as well as Algafix+Amalgerol (89.91\%) and the Amalgerol+Fitohorm Turbo Zn (89.81\%) treatments. The incensement compared the control $(89.62 \%)$ was slight (Figure 3 ). The different treatments did not increase this parameter significantly on $\mathrm{P}=5 \%$ level, because it is highly dependent on the genetical characteristics of hybrid.

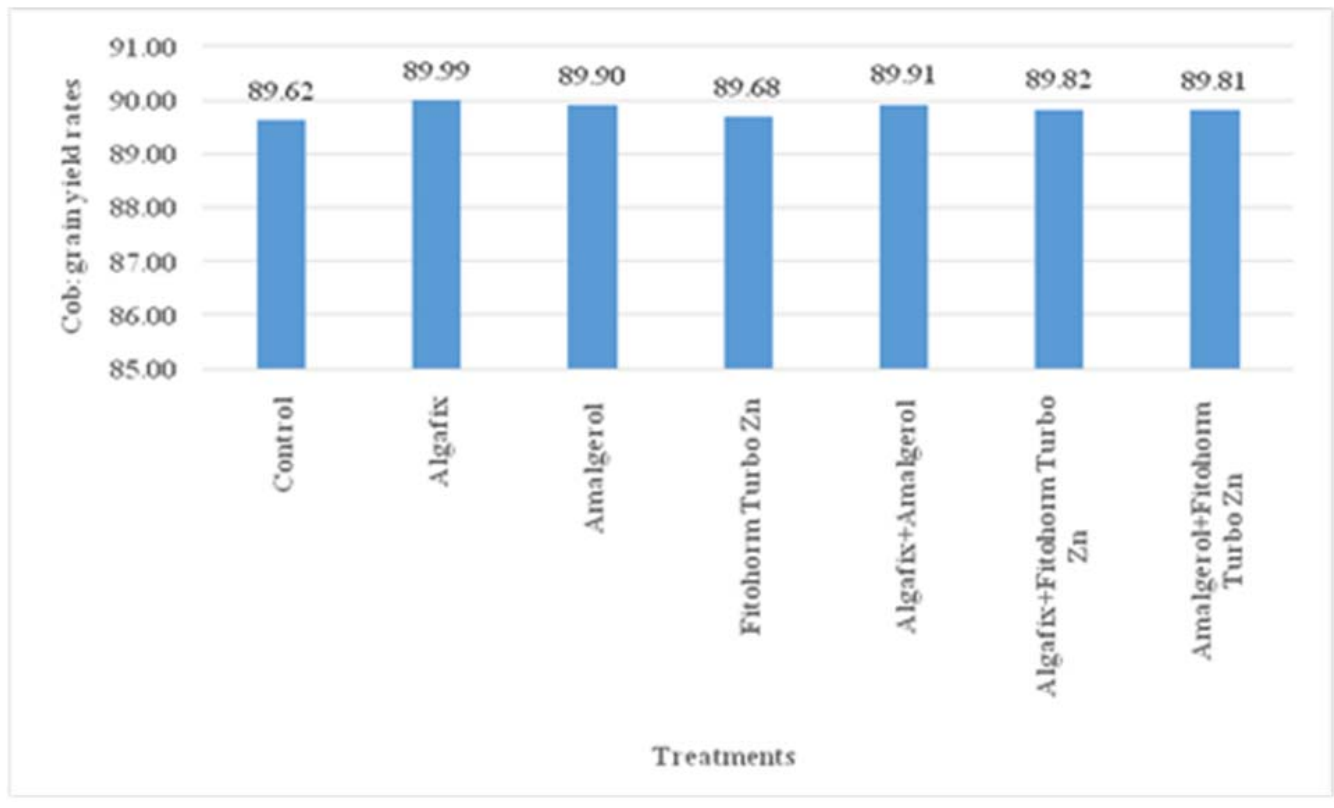

Fig. 3. The effect of foliar fertilization on the cob: grain yield rates 
The grain moisture content at harvest is an essential measure of maize value. It is important that the hybrids should have low grain moistures at harvest, then the cost of drying can be reduced and also the profitability of maize production can be increased. The grain moisture content of control plots were $16.35 \%$. In treated parcels we measured $15.83-16.52 \%$. The difference was not significant between control and treated results. The Amalgerol+Fitohorm Turbo $\mathrm{Zn}(15.83 \%)$ and the Algafix+Amalgerol (15.89\%) treatments results the lowest grain moisture content at harvest (Figure 4).

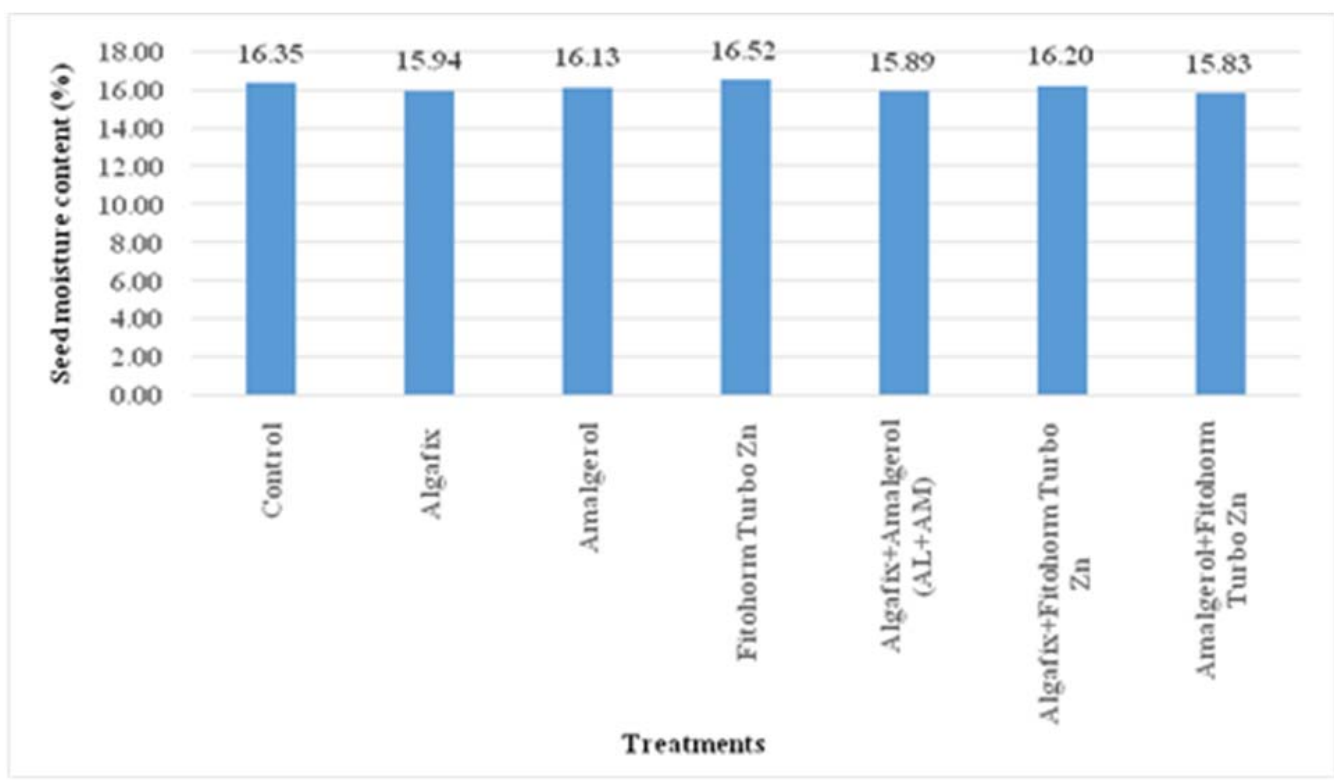

Fig. 4. The influence of foliar fertilization on the seed moisture content at harvest

\section{Conclusions}

The year 2016 was favourable for maize production. Therefore the control yield of maize was relatively high, $11.37 \mathrm{t} / \mathrm{ha}$. The different foliar fertilizer products increased the maize yield with $0.24-1.49 \mathrm{t} / \mathrm{ha}$, but it was not statistically justified on $\mathrm{P}=5 \%$ level.

The generative factors did not change significantly either when using foliar fertilizer products. Our results proved that the foliar fertilization can increase the yield of maize in the case of favourable weather conditions; therefore it has an importance in maize production. The results of the experiment provide information only in case of the given test area; no general conclusions can be drawn. To make adequate statements, severalyears experiment is necessary. Therefore we would like to continue our experiment.

\section{References}

1. Kovács, P., Sárvári, M. (2016), The effect of some agrotechnical factors on the yield of maize hybrids with different genetic base. Növénytermelés. 65 . (Supplement) 103-106.

2. Horváth, J., Komarek, L. (2016), A világ mezőgazdaságának fejlödési tendenciái. Szegedi
Tudományegyetem Mezőgazdasági Kar, Hódmezővásárhely, 270 (ISBN: 978963306496 2)

3. Komarek, L. (2006), A rendszerváltozás utáni strukturális változások főbb jellemzői a Dél-Alföld mezőgazdaságában. In: Kertész Á, Dövényi Z, Kocsis K (szerk.). III. Magyar Földrajzi Konferencia: absztrakt kötet + CD-ROM. 238 p. Konferencia helye, ideje: Budapest, Magyarország, 2006.09.06-2006.09.07. Budapest: MTA Földrajztudományi Kutatóintézet, Paper rendszerváltozás, 10. (ISBN:963-9545-12-0)

4. Komarek, L. (2007), A Dél-Alföldi Régió súlyának, szerepének alakulása a hazai agrártermelésben. COMITATUS: ÖNKORMÁNYZATI SZEMLE 17. évf.:(9. sz.) $52-64$.

5. Komarek, L. (2007), The structural changes in the agriculture of the South Great Plain since the regime change. In: Kovács Csaba (szerk.)From villages to cyberspace: In commemoration of the 65th birthday of Rezső Mészáros, Academician: Falvaktól a kibertérig: Ünnepi kötet Mészáros Rezső akadémikus 65. születésnapjára.471 p. $\quad$ Szeged: SZTE Természettudományi és Informatikai Kar Gazdaság- és Társadalomföldrajz Tanszék, 329-339. (ISBN:978 963 482809 9)

6. Komarek L. (2008), A Dél-Alföld agrárszerkezetének sajátosságai.Szeged: Csongrád Megyei Agrár Információs Szolgáltató és Oktatásszervező Kht, 143. (ISBN:978-963-06-5325-1) 
7. Kádár, I. (2008), A levéltrágyázás jelentősége és szerepe a növénytáplálásban. Acta Agronomica Óváriensis. Vol. 50. No.1. 19-27.

8. Hoffmann, R., Varga, Cs., Karika, A. (2014), Levéltrágyázás a gyakorlatban. Agrárium. 24. 8. 69-72.

9. Jakab, P., Komarek, L. (2017), The effect of foliar application on different fertilizers on technological and economical parameters of maize. Infrastructure and Ecology of Rural Areas, Krakow, (in. presss)

10. Kincses, S-Né, Filep, T., Loch, J. (2002), Az NPKtrágyázás hatása a kukorica tápelemfelvételének dinamikájára öntözött és nem öntözött viszonyok között. Acta Agraria Debreceniensis. 1. 23-27.

11. Kincses, S-Né, Nagy, T., Balláné Kovács A., Filep, T. (2005), Az NPK-trágyázás hatása a búza (Triticum aestivum) és a kukorica (Zea mays) $\mathrm{Zn}$ felvételére. Acta agronomica Óváriensis. 47. 1. 239252.

12. Jakab, P., Zoltán, G., Komarek, L. (2016), The effect of foliar fertilization on the yield and generative factors of maize. Review on Agriculture and Rural Development. 5 (1-2). 158-161.

13. Zoltán, G., Jakab, P. (2016), Lombtrágya készítmények hatása a kukorica termésére és beltartalmára. In: Szalka Éva, Bali Papp Ágnes (szerk.), XXXVI. Óvári Tudományos Nap: Hagyomány és innováció az agrár- és élelmiszergazdaságban II. 335 p. Konferencia helye, ideje: Mosonmagyaróvár, Magyarország, 2016.11.10 Mosonmagyaróvár: Széchenyi István Egyetem Mezőgazdaság- és Élelmiszertudományi Kar, 2016. 246-251.(ISBN:978615-5391-79-8)

14. Dorneau, A., Borlan, Z., Popa, O., Dumitru, M., Dorneau, E. (2005), Ingrasamintele foliare-mijloc important de fertilizare suplimentara in timpul vegetatiei plantelor. Raportul optim intre fertilizarea de baza si fertilizarea foliara. CIEC Symposium, 127-136.

15. Rusu, M., Marghitas, M., Michaiescu, T., Oroian, I., Todea, A., Bordea, C, Toader, C. (2008). Fertilizantii foliari - conditii agrochimice de aplicare. Lucrari Conf. XVIII. SNRSS. vol. 2. 75-85.

16. Ryan, J. (2002), Fertilizers, applications, methods. Encyclopedia of Soil Sciences. Marcel Dekker Inc. New York. 553-556.
17. Toader, C., Marghitas, M., Rusu, M., Mihai, M. (2012), Research on alternatives and strategies for foliar fertilization within differentiated fertilization systems for maize crop. Research Journal of Agricultural Science. 44. (1). 163-167.

18. Jakab, P., Futó, Z., Lévai, K., Nagy, P. (2004), A tápanyagellátás hatása az őszi búza fajták termésére. Összefoglaló. [In: Kalmár I. (ed.) IV: alföldi Tudományos Tájgazdálkodási Napok] Tessedik Sámuel Föiskola Mezőgazdasági Főiskolai Kar, Mezőtúr 113.

19. Jakab, P. (2010), Talajbaktérium készítmények alkalmazása a fenntartható növénytermesztésben. Összefoglaló. [In: Kóródi M. (ed.) Tudomány határok nélkül: Válságjelenségek összefüggései a gazdaságban és a társadalomban]. Szolnoki Föiskola, Szolnok, 99.

20. Jakab, P., Jakabné, Nagy P. (2013), Environmentally friendly nutrient supply of spring barley. Review on Agriculture and Rural Development, vol. 2. (1). 274-277.

21. Jakab, P., Jakabné Nagy P. (2013), Use of soil bacterium preparation in the spring barley production. Lucrari Stiintific Management Agricol, 15: (1). 35-39.

22. Jakab, P., Komarek, L., Zoltán, G. (2016), The study of foliar fertilization in maize production, In: Futó $Z$ (szerk.). Kihívások a mai modern mezőgazdaságban. Magyar Tudomány Napja Konferencia Kiadványa, Szent István Egyetemi Kiadó, Gödöllö, 197-202

23. Tukey J. W. (1985), The problem of multiple comparisons (1953) (unpublished manuscript). The Collected Works of John W. Tukey, Volume II: Time Series, Wadsworth Advanced Books \& Software, Monterey, CA. 1965-1984

24. Makra, L., Sánta, T., Matyasovszky, I., Damialis, A., Karatzas, K., Bergmann, K. C., Vokou, D. (2010), Airborne pollen in three European cities: Detection of atmospheric circulation pathways by applying threedimensional clustering of backward trajectories. Journal of Geophysical Research-Atmospheres, 115 (24): 16. DOI: 10.1029/2010JD014743

25.Makra L., Ionel I., Csépe Z., Matyasovszky I., Lontis N., Popescu F., Sümeghy Z. (2013), The effect of different transport modes on urban PM10 levels in two European. Science of the Total Environment. 458460: 36-46. doi.org/10.1016/j.scitotenv.2013.04.021 